Proceedings of the 2018 International Scientific Conference 'Economic Sciences for Agribusiness and Rural Economy' No 1, Warsaw, 7-8 June 2018, pp. 287-293

\title{
ENVIRONMENTAL POLICY IMPLEMENTATION BASED ON INNOVATIVE COMPONENT - EXPERIENCE OF UKRAINE
}

\section{Serhiy Zabolotnyy, $\mathrm{PhD}^{1}$; Olena Shust, $\mathrm{PhD}^{2}$; Olha Babytska, $\mathrm{PhD}^{3}$; Tamara Prykhodko ${ }^{4}$}

${ }^{1}$ Faculty of Economic Sciences, Warsaw University of Life Sciences - SGGW

2, 3, 4 Faculty of Economics, Bila Tserkva National Agrarian University

\begin{abstract}
The article presents the principles of environmental policy implementation in Ukraine and its social, economic and ecological impact in accordance with objectives of the Environmental Strategy of Ukraine for 2020. It is stated that activities of industrial enterprises lead to the most significant negative influence on the environment. The relation between environmental policy and atmospheric air emissions is determined using regression analysis. It is also proved that innovations can be viewed as a driver for realization of environmental policy. Measures for the environmental policy improvement in Ukraine refer to state and local control and imply a set of innovative actions in industrial production.
\end{abstract}

Keywords: environmental policy, sustainability, innovation, effect JEL codes: O31, O44, Q55

\section{INTRODUCTION}

Principles of environmental policy of Ukraine are stated in the Law of Ukraine on the Basic Principles of the National Environmental Policy of Ukraine for 2020 which was adopted in 2010. After seven years social and environmental aspects were ousted by urgent matters of a lasting profound economic transformation. According to the State Statistics Service of Ukraine, the population of the country decreased by $7 \%$ in 2016 against 2011 and came to 42.6 million people by 1 January 2017. In 2016 the number of deaths per 1,000 people exceeded births
1.4 times. The average air temperature in Ukraine increased in all regions from $0.5^{\circ} \mathrm{C}$ to $1.7^{\circ} \mathrm{C}$ in 2016, compared with the average for 2001-2005 (State Statistics Service of Ukraine database). In these circumstances achieving objectives of the environmental strategy based on scientific and technological progress and best practices, i.e., innovations, is to be considered as a national priority. This strategy addresses 'weaknesses' of the national environmental policy and allows to concentrate on efficient measures to eliminate the negative impact of business operations on the environment and society.

${ }^{1}$ Corresponding author: Nowoursynowska 166,02-787 Warsaw, Poland, serhiy_zabolotnyy@sggw.pl, +48 693747972

${ }^{2}$ Corresponding author: pl. Soborna 8/1, Bila Tserkva, Ukraine, elenshust08@ukr.net, +38 (067) 67612112

${ }^{3}$ Corresponding author: pl. Soborna 8/1, Bila Tserkva, Ukraine, babitskaya_olga@ukr.net, +38 (096) 5580204

${ }^{4}$ Corresponding author: pl. Soborna 8/1, Bila Tserkva, Ukraine, ratamy@bigmir.net, +38 (067) 96966115 


\section{THEORETICAL BACKGROUND}

Issues of environmental policy and its implementation at different levels were studied by Karaczun (2005), Kravets (2006), Zharova (2008), and others. Besides the ecological component of sustainable development was discussed by Hens and Melyk (2008), Kuchkova (2008), Hełdak and Raszka (2011). The role of innovations in economics is presented in works of Ilyashenko (2011), Przychodzen and Przychodzen (2015), Hojnik and Ruzzier (2016). The literature review demonstrates a limited attention to the problem of innovations as an instrument of environmental policy implementation in Ukraine.

\section{MATERIALS AND METHODS}

The goal of the research is to evaluate the progress on environmental policy implementation in Ukraine with reference to its innovation component in 2011-2016. To achieve the objective authors have analysed a national environmental policy, including factors influencing emissions of carbon dioxide $\left(\mathrm{CO}_{2}\right)$ into atmosphere, and presented measures for its improvement. Indicators of innovations of industrial companies in Ukraine have also been studied. The research is based on the data of the State Statistics Service of Ukraine devoted to emissions of pollutants and degree of innovations of industrial enterprises. Regression analysis was used to determine relations between the volume of emissions of air pollutants and indicators of industrial innovations.

\section{RESULTS AND DISCUSSION}

Environmental policy is usually defined as a set of public activities aimed at preserving the environment, which simultaneously ensures harmonic development of society and economic efficiency (Zharova, 2008). In our opinion, the implementation of environmental policy should be consistent with demand, production and technological capacity of the economy. The concept of innovation considers these facets since it must meet requirements of consumers and give profit to all subjects of the innovation process - both developers and manufacturers. In this regard, inno- vation activities should primarily target the use and commercialization of the research and development results to provide new competitive goods and services (Illyashenko, 2011). The innovative component of environmental policy refers to the development and implementation of innovations in order to maintain business efficiency in accordance with principles of environmental protection (Hojnik and Ruzzier, 2016).

The implementation of a national environmental policy can be evaluated on the basis of efficiency measures, which according to Environmental Strategy of Ukraine for 2020 are divided into several groups, covering such aspects as level of ecological consciousness in society, environmental pollution and protection, integration of environmental policy; biodiversity, renewable and innovative energy sources and regional environmental policy (Parliament of Ukraine, 2010). Aforementioned aspects can be illustrated by a set of indicators (Table 1).

According to the Ministry of Ecology and Natural Resources of Ukraine for 2011-2016 only 32 indicators of the Strategy out of 76 were achieved. At the same time, some ecological effect was gained due to reduction of air pollutant emissions produced by stationary sources of pollution, with the largest share of carbon dioxide emissions. However, it is the crisis in the Ukrainian economy rather than environmental measures that caused emission reductions. Besides real GDP per capita decreased from EUR 2.2 thousand in 2011 to EUR 1.7 thousand in 2016. The average life expectancy at birth for both men and women in Ukraine is the lowest compared to the countries of the European Union. Besides against a reduction in budget for environmental measures, the share of expenditures on environmental protection in budget expenditures decreased from $1.1 \%$ in 2013 to $0.7 \%$ in 2016 (State Statistics Service of Ukraine database).

The issue of wastes and their processing remains quite topical in Ukraine since the process of implementing innovative methods of utilization has intensified in recent years. Waste in Ukraine is utilized in two ways - by burning and burial. There are 4 incinerator plants located in Kyiv, Dnipropetrovsk, Kharkiv and Sevastopol, and only Kyiv plant 'Energia' oper- 
Proceedings of the 2018 International Scientific Conference 'Economic Sciences for Agribusiness and Rural Economy' No 1, Warsaw, 7-8 June 2018, pp. 287-293

Table 1. Indicators of environmental policy of Ukraine in 2011-2016

\begin{tabular}{|c|c|c|c|c|c|c|c|c|}
\hline \multirow{2}{*}{ Indicator } & \multirow{2}{*}{2011} & \multirow{2}{*}{2012} & \multirow{2}{*}{2013} & \multirow{2}{*}{2014} & \multirow{2}{*}{2015} & \multirow{2}{*}{2016} & \multicolumn{2}{|c|}{2016 against 2011} \\
\hline & & & & & & &,+- & $\%$ \\
\hline $\begin{array}{l}\text { Total emissions of air pollutants } \\
\text { (thous. tonnes), incl.: }\end{array}$ & 4374.6 & 4335.3 & 0 & 0 & 2857.4 & 3078.5 & -1296.1 & 70.4 \\
\hline Industrial enterprises & 3937.1 & 4031.8 & 3736.7 & 3048.5 & 2571.7 & 2739.9 & -1197.3 & 69.6 \\
\hline Per capita in Ukraine $(\mathrm{kg})$ & 150.5 & 149.6 & 147.7 & 124.3 & 105.5 & 72.1 & -78.4 & 0 \\
\hline $\begin{array}{l}\text { Total } \mathrm{CO}_{2} \text { emissions (million tonnes), } \\
\text { incl.: }\end{array}$ & 236.0 & 232.0 & 230.7 & 194.7 & 162.1 & 150.6 & -85.4 & 63.8 \\
\hline $\mathrm{CO}_{2}$ emissions of industrial enterprises & 202.2 & 198.2 & 197.6 & 166.9 & 138.9 & 150.6 & -51.6 & 74.5 \\
\hline $\begin{array}{l}\text { Total volume of wastes (million } \\
\text { tonnes) }\end{array}$ & 447.6 & 450.7 & 448.1 & 355.0 & 312.3 & 295.9 & -151.7 & 0 \\
\hline $\begin{array}{l}\text { Dumping of contaminated water } \\
\left(\text { million } \mathrm{m}^{3}\right)\end{array}$ & 7725 & 7788 & 7440 & 6354 & 5343 & 5399 & -2326.0 & 69.9 \\
\hline Lands violated (thous. ha) & 1.2 & 1.2 & 1.0 & 0.9 & 0.9 & 1.0 & -0.2 & 83.3 \\
\hline $\begin{array}{l}\text { Utilized waste of I-IV classes of } \\
\text { danger (thous. tonnes) }\end{array}$ & 153.7 & 143.5 & 147.2 & 109.3 & 92.5 & 84.6 & -69.1 & 55.0 \\
\hline Reforestation (thous. ha) & 71.0 & 69.0 & 66.7 & 58.0 & 60.4 & 63.2 & -2326.0 & 69.9 \\
\hline $\begin{array}{l}\text { Total budget expenditures on } \\
\text { environmental measures (EUR } \\
\text { million), incl.: }\end{array}$ & 350.8 & 515.8 & 527.2 & 221.5 & 228.2 & 222.1 & -128.7 & 63.3 \\
\hline $\begin{array}{l}\text { Share of total budget expenditures } \\
\text { on environmental measures in total } \\
\text { budget expenditures (\%) }\end{array}$ & 0.9 & 1.1 & 1.1 & 0.7 & 0.8 & 0.7 & -0.2 & 0 \\
\hline Environmental tax paid (EUR thous.) & 0 & 0 & 0 & 0 & 0 & 0 & -90.5 & 0 \\
\hline Mortality rate (thous. people) & 664.6 & 663.1 & 662.4 & 632.3 & 594.8 & 583.6 & -81.0 & 87.8 \\
\hline $\begin{array}{l}\text { Average life expectancy at birth } \\
\text { (years) }\end{array}$ & 71.02 & 71.15 & 71.37 & 71.37 & 71.38 & 71.68 & 0.65 & 100.9 \\
\hline
\end{tabular}

Source: own research based on materials of State Statistics Service of Ukraine.

ates. This plant processes up to $28 \%$ of all rubbish in Ukraine, while plants in Sweden process up to $99 \%$, and produce energy from the secondary raw materials. Moreover, in Ukraine up to 30 thousand unauthorized landfills appear each year (Ivanova, 2015). Countries of the European Union have eliminated illegal landfills, and sorting wastes has become a common practice for the population (Hełdak and Raszka, 2011).
The 'leader' in environmental pollution is industry (in particular processing and mining sectors) as well as electric, gas and steam supply companies, while the largest amount of pollutants emitted into the air and water basins comes from powerful industrial regions of Ukraine - Donetsk, Lugansk, Dnipro, Kyiv, Sumy (State Statistics Service of Ukraine database). Hence, the efforts of national policy should be directed to the introduction of innovative measures 
to reduce the negative influence of industry on environment. Innovations' implementation should lead to the reduction of energy and material consumption, increase of recycled production use, lowering of emissions and dumping into air and water basins and intensification of new technological processes (Table 2). Nowadays, managers of business units by pursuing a profit maximization strategy, often neglect the resource potential reproduction, and, moreover, do not consider harmful effect of business on environment. The increase in the number of low-waste and resource-saving technologies $(+231$ units) is a vector for further balanced development not only for the industry, but also for the economy of the country. Of course, innovative actions require additional investment, and the payback period of innovative projects often takes more than a year. As we can see the revenue from selling of innovative products dropped by $58.4 \%$. Regarding this fact it should be mentioned that the share of expenditures on research and development in Ukrainian GDP is 5-7 times lower than in countries of Central Europe, in particular in Poland, Slovakia, Bulgaria and Ro- mania, and 20 times lower than the average for the European Union (Karaczun, 2005).

Taking into account that innovative development is the driver for the achievement of the national environmental strategy objectives, we assume that the human factor as well as the capacity of business innovations can significantly impact the environment, including the rate of $\mathrm{CO}_{2}$ emissions into atmosphere (Table 3).

Thus, according to Table 3 , we obtained an equation which describes the dependence of carbon dioxide emission into atmospheric air on innovative factors: $Y=344,127.7-5,248.0 x_{1}-6,966.9 x_{2}$, $\mathrm{R}^{2}=0.37$.

The model shows a moderate linear dependence between $\mathrm{CO}_{2}$ emissions into air, number of employees engaged in innovative projects and share of innovative enterprises. In particular, an increase in the number of workers by 1,000 people and an increase in the level of innovative activity of industrial enterprises by $1 \%$ will allow to reduce the amount of carbon dioxide emissions by 5,248 and 6,966.9 thousand tonnes, respectively.

Table 2. Innovative actions of industrial enterprises in the context of environmental policy implementation for 2011-2016

\begin{tabular}{|l|c|c|c|c|c|c|c|c|}
\hline Specification & 2011 & 2012 & 2013 & 2014 & 2015 & 2016 & \multicolumn{2}{|c|}{2016 against 2011} \\
\cline { 5 - 9 } & & & & & & \\
\hline $\begin{array}{l}\text { Share of enterprises that carried out } \\
\text { innovations in the total amount of industrial } \\
\text { enterprises (\%) }\end{array}$ & 16.2 & 17.4 & 16.8 & 16.1 & 17.3 & 18.9 & 2.7 & 0 \\
\hline $\begin{array}{l}\text { Number of employees involved in } \\
\text { the development (implementation) of } \\
\text { innovations (thous. people) }\end{array}$ & 7.4 & 8.8 & 8.9 & 11.2 & 9.4 & 10.5 & 3.1 & 0 \\
\hline $\begin{array}{l}\text { Volume of revenue from selling of } \\
\text { innovative products (EUR million) }\end{array}$ & 0.74 & 0.91 & 1.08 & 0.87 & 0.37 & 0.31 & -0.43 & 0 \\
\hline $\begin{array}{l}\text { The volume of innovations financing by the } \\
\text { enterprises of the industry (EUR million) }\end{array}$ & 0.25 & 0.29 & 0.29 & 0.26 & 0.22 & 0.18 & -0.07 & 0 \\
\hline $\begin{array}{l}\text { Total number of implemented new } \\
\text { technological processes, incl.: }\end{array}$ & 2510 & 2188 & 1576 & 1743 & 1217 & 3489 & 979 & 0 \\
\hline Low-waste and resource-saving & 517 & 554 & 502 & 447 & 458 & 748 & 231 & 0 \\
\hline
\end{tabular}

Source: own research based on materials of State Statistics Service of Ukraine. 
Proceedings of the 2018 International Scientific Conference 'Economic Sciences for Agribusiness and Rural Economy' No 1, Warsaw, 7-8 June 2018, pp. 287-293

Table 3. Data for determining the dependence between carbon dioxide emissions by industrial enterprises of Ukraine, the number of employees involved in the development (implementation) of innovations, and the level of innovation activity of industrial enterprises, 2004-2016

\begin{tabular}{|c|c|c|c|}
\hline Year & $\begin{array}{c}\mathrm{CO}_{2} \text { emissions into air, } Y_{1} \\
\text { (thous. tonnes) }\end{array}$ & $\begin{array}{l}\text { Number of employees involved in } \\
\text { the development (implementation) } \\
\text { of innovations, } X_{1}^{*} \\
\text { (thous. people) }\end{array}$ & $\begin{array}{c}\text { Share of innovative } \\
\text { industrial enterprises, } X_{2} \\
(\%)\end{array}$ \\
\hline 2004 & 126882.2 & 43331 & 14.9 \\
\hline 2005 & 152008.1 & 43238 & 11.9 \\
\hline 2006 & 178760.5 & 43268 & 11.2 \\
\hline 2007 & 183962.9 & 43118 & 14.2 \\
\hline 2008 & 174234.0 & 43237 & 13.0 \\
\hline 2009 & 152809.1 & 43147 & 12.8 \\
\hline 2010 & 165000.0 & 43203 & 13.8 \\
\hline 2011 & 202222.0 & 43197 & 16.2 \\
\hline 2012 & 198175.1 & 43320 & 17.4 \\
\hline 2013 & 197618.0 & 43351 & 16.8 \\
\hline 2014 & 166936.7 & 43142 & 16.1 \\
\hline 2015 & 138932.1 & 43199 & 17.3 \\
\hline 2016 & 150581.0 & 43230 & 18.9 \\
\hline
\end{tabular}

*Including employees from other sectors (education, scientific institutes, etc.) engaged in elaboration of innovations for industrial enterprises.

Source: own research based on data from State Statistics Service of Ukraine.

Undoubtedly, some attempts to improve the ecological situation in Ukraine have already been made. For example a construction of a protective arch, built over the old sarcophagus of the fourth power unit of the Chernobyl nuclear power plant in November 2016 should be mentioned in this regard. The Ministry of Ecology and Natural Resources of Ukraine has developed the National Strategy for Waste Management for 2030. Here attention is drawn to the expected results of stimulating business entities to operate using non-waste and innovative and environmentally safe technologies. However, the mechanism of implementation of this principle is not explained in the new strategy (Regulation of Cabinet of Ministers No 820-r 2017).

\section{CONCLUSIONS}

The results of the study showed that, despite the elaboration of the National Environmental Strategy of Ukraine for 2020, its implementation status cannot be considered as satisfactory. Some figures of the strategy remain uncontrolled or not accounted by State Statistics Service of Ukraine. This calls into question the real status of the implementation of the Strategy.

Anthropogenic and technogenic impact on the environment in Ukraine is several times higher than in the developed countries of the world. According to the World Bank and the International Institute for Sustainable Development, Ukraine is ranked as 153rd 
in the world according to the level of the indicator of sustainable development. Finland, Sweden, Norway, Switzerland, Luxembourg, Denmark, Canada, Ireland and Australia were ranked as ten most progressive countries in terms of economic and social development and environmental protection measures in 2016.

The process of implementation of environmental policy considering innovative approaches in Ukraine is rather slow. The dynamics of innovative activity of industrial enterprises - the largest polluters of the environment - demonstrates, on the one hand, the achievement of a certain ecological effect, and, on the other hand, decrease in operations. Therefore, it is necessary to eliminate the disparities between the economic development of industrial enterprises and their impact on environment, which ultimately affect the health of the nation. Motivational factors for the introduction and implementation of innovations by industrial enterprises, i.e. tax breaks, special conditions for obtaining credits with partial reimbursement of interest from the state, material incentives for employees involved in innovative activities, increase of direct state financial support for innovations can be viewed as a necessary condition for meeting the principles of environmental strategy. In other words, it is the state that must create the demand for innovation in business.

The direct inverse relationship between the level of innovation activity of industrial enterprises, the number of employees involved in the development and implementation of innovations, and the amount of carbon dioxide emissions into the atmosphere confirms that innovations can be viewed as a driver for realization of the environmental policy in Ukraine. We believe that the priority measures to improve the environmental policy should include, first of all, strengthening the state control in pursuing the goals of environmental strategy both among enterprises and population in order to create environmental awareness and responsibility. Regarding this directions of further research are seen in the development of measures to integrate environmental policy of Ukraine into the European vector in order to improve the living standards of the population and attract investments. Such measures will enable to achieve the main principle of sustainable development aiming at preserving the environment and not depriving future generations of the possibility to meet their natural needs.

\section{REFERENCES}

Hełdak, M., Raszka, B. (2011). Prognosis of Natural Environment Transformations Resulting from Spatial Planning Solutions. Polish Journal of Environmental Studies, 20 (6), pp. 1513-1518.

Hens, L., Melnyk, L. (2008). Social and economic potential of sustainable development. University book, Sumy.

Hojnik, J., Ruzzier, M. (2016). What drives eco-innovation? A review of an emerging literature. Environmental Innovation and Societal Transitions, 19, pp. 31-41.

Illyashenko, S.M. (2011). Rol innovacii i innovaciinoii diialnosti u socialno-ekonomichnomu rozvytku [The role of innovations and innovative activity in the social and economic development]. Zbirnyk naukhovyh prac Khmelnytskogo kooperatyvnogo torhovelno-ekonomichnoho instytutu. Khmelnyckii derzhavnyi centr nauky, innovacii tainformatyzacii. Khmelnyckii, 2, pp. 90-101.

Ivanova, I.V. (2015). Stan i problemy utylizacii i vydalennia pobutovyh i promyslovyh vidhodiv v Ukraini i kraiinah ES [State and problems of utilization and recycling of mode and industrial wastes in Ukraine and countries of EU]. Naukovo-tekhnichna Informatsiia, 2, pp. 46-52.

Kabinet Ministrov Ukrayiny rozporyadzhennya vid 8 lystopada 2017 r. No 820-r Kyiv pro skhvalennya Natsional'noyi stratehiyi upravlinnya vidkhodamy v Ukrayini do 2030 roku [Regulation of Cabinet of Ministers of Ukraine on submission of National Strategy of Waste Management in Ukraine till 2030].

Karaczun, Z. (2005). Preparing for EU environmental policy in Poland: The case of the nitrates directive. Land Use Policy, 22 (3), pp. 245-253.

Kravets, M.O. (2006). Metodychni zasady ekolohichnoii polityky [Methodical aspects of ecological policy]. Ecolohichnyi menedzhment: zbirnyk naukhovyh prac. MAUP, Kyiv, pp. 121-123.

Kuchkova, N.V. (2006). Ekolohichnyi menedzhment u stratehiii staloho rozvutku Ukrainy [Ecological management in the strategy of sustainable development of Ukraine: theoretical aspect]. Ecolohichnyi menedzhment: zbirnyk naukhovyh prac. MAUP, Kyiv, pp. 59-62.

Przychodzen, J., Przychodzen, W. (2015). Relationships between eco-innovation and financial performance - evidence from publicly traded companies in Poland and 
Proceedings of the 2018 International Scientific Conference 'Economic Sciences for Agribusiness and Rural Economy' No 1, Warsaw, 7-8 June 2018, pp. 287-293

Hungary. Journal of Cleaner Production, 90, pp. 253263.

Zakon Ukrayiny Pro Osnovni zasady (stratehiyu) derzhavnoyi ekolohichnoyi polityky Ukrayiny na period do 2020 roku [Law of Ukraine on main bases (strategy) of state ecological policy of Ukraine till 2020]. Journal of Laws 2011 No 2818-VI.
Zharova, L.V. (2008). Suchasna ekolohichna polityka: chynnyky vplyvu ta pidhody do formuvannia [Modern ecologic policy, its factors of influence and approaches to the forming]. Nauka moloda: zbirnyk naukhovyh prac molodyh vchenyh Ternopilskoho natsionalnoho ekonomichnoho universytetu. Ternopil, 10, pp. 136-140. 